\title{
HOW DO PROSPECTS OF EU MEMBERSHIP INFLUENCE SUPPORT FOR SECESSION? A SURVEY EXPERIMENT IN CATALONIA AND SCOTLAND
}

\author{
Diego Muro and Martijn C. Vlaskamp
}

\section{Correspondence details}

Diego Muro, Institut Barcelona d'Estudis Internacionals (IBEI), Edifici Mercè Rodoreda, Campus de la Ciutadella (Universitat Pompeu Fabra), c/Ramon Trias Fargas 25-27, 08005 Barcelona, Spain. Email: dmuro@,ibei.org, Phone: +34 93.542.3037 (Corresponding author).

Martijn C. Vlaskamp, The Whitney and Betty MacMillan Center for International and Area Studies at Yale, PO Box 208206, New Haven CT 06520-8206, United States. Email: martijn.vlaskamp@yale.edu, Phone: +1 203.432.6016

\section{$\underline{\text { Notes on contributors }}$}

Diego Muro is Assistant Professor in Comparative Politics at the Institut Barcelona d'Estudis Internacionals (IBEI). His main research interests are nationalism and ethnic conflict, social movements, and terrorism studies [dmuro@ibei.org]. Martijn C. Vlaskamp is a Marie Skłodowska-Curie Global Fellow at the Institut Barcelona d'Estudis Internacionals (IBEI) and the Whitney and Betty MacMillan Center for International and Area Studies at Yale University. He works on EU Foreign Policy, and the role of natural resources in armed conflicts [mvlaskamp@ibei.org or martijn.vlaskamp@yale.edu].

\section{$\underline{\text { Acknowledgements }}$}

The authors are grateful to Guillem Vidal Lorda for valuable research assistance and two anonymous reviewers for their helpful feedback.

\section{Funding}

This work was supported by the Fritz Thyssen Foundation under grant number Az.20.14.0.032. 


\begin{abstract}
$\underline{\text { Abstract }}$
The past years have been eventful for secessionist movements in Europe and in particular in Scotland and Catalonia. Supporters and opponents of secession of both stateless nations considered their prospects for future EU membership as an important part of the campaigns leading to the referendums. The article's aim is to explore whether international factors influence domestic support for secession.

In order to answer this puzzle, we carried out an on-line survey experiment $(n=2,408)$ in Catalonia and Scotland in which we confronted our respondents with different scenarios concerning the EU membership of their hypothetical new state (inclusion or exclusion).

Contrary to the general perception, the prospects of EU membership had only a limited effect on support for the creation of a sovereign state. Moreover, we found that the impact of our treatments was strongly mediated by the participants' previous degree of nationalism and their attitudes with respect to the EU.
\end{abstract}

\title{
$\underline{\text { Keywords }}$
}

Separatism, nationalism, referendum, Spain, UK, survey experiment

\section{$\underline{\text { Word count }}$}

8,924 words (including references, tables, figures and appendix) 


\section{Main text}

\section{Introduction}

The past years have been eventful for secessionist movements in Europe and in particular in Scotland and Catalonia. Scotland held a referendum on independence in 2014, and Catalonia's 2015 regional elections were framed as a plebiscite on secession from Spain. In both regions, the future EU membership of the potential new state played a prominent role in debates about the advantages and disadvantages of independence. Regional governments in favour of secession talked about a smooth accession to the EU (Ayadi et al. 2015; Consell Assessor per a la Transició Nacional 2014; Scottish Government 2014). By contrast, counterarguments by the Spanish and British governments ranged from simply pointing out the complex negotiations that an accession process would involve (HM Government 2014) to categorically ruling out EU membership (Spanish Ministry of Foreign Affairs and Cooperation 2013: 109ff). Both the secessionist and unionist sides thus attributed considerable importance to the issue of EU membership and saw it as an important element of their campaigns to convince citizens of their positions (Bourne 2014). In the case of Catalonia, the Spanish Minister of Foreign Affairs even met with one of the leaders of the pro-independence camp to debate this issue on prime time television (García Pagan 2015).

These discussions on EU membership are the starting point of this paper. Little scholarly research has examined the extent to which international factors influence support for secession. Most research on separatism has focused on domestic demand for political independence, whereas only a handful of authors have studied the international dimension of secession (Caspersen 2011; Ker-Lindsay 2012). In this article we want to contribute to closing this research gap by testing whether the prospects of EU membership can have a significant influence on support for secession in European stateless nations.

To answer this question, we have carried out an on-line survey experiment $(n=2,408)$ in Catalonia and Scotland in which we confronted the respondents with three different scenarios regarding EU inclusion (or exclusion). Our findings suggest that the prospects concerning EU membership can indeed affect support for independence in a variety of contexts. However, the impacts are not as strong as politicians and activists engaged in the public debate might expect. We find a moderating effect of the issue of EU membership according to pre-established 
preferences of individuals and argue that, on the whole, only citizens with moderate nationalist beliefs and pro-European attitudes are influenced.

The article is structured as follows. The second section examines how the Union's institutional structures may stimulate and/or discourage support for secession in its Member States. The third section specifies a series of hypotheses about the relationship between the prospects of EU membership and support for secession. The fourth section introduces the research design of the survey experiment and explains how the hypotheses were tested. Section Five presents and discusses the results of the on-line survey for the cases of Catalonia and Scotland. Finally, the concluding section summarises the main findings.

\section{Analytical Framework: How Does the EU Incentivise or Discourage Secessionism in Its Member States?}

At first sight the idea of seceding from an EU Member State seems to run contrary to the idea of blurring boundaries in an 'ever closer Union'. It may appear paradoxical to promote the separation from a state and the erection of new borders while aspiring to be integrated in a political community beyond the nation-state. Yet, the most visible secessionist movements embrace a European identity and a political vision that combines the elimination of barriers with the erection of supra-national decision-making bodies. The goal of this section is to explain how the EU's structure may stimulate support for an independent state while discouraging the act of secession.

Secessionist movements fight for independence by appealing to the emotions of voters and by constructing a convincing story based on cultural, economic, or political motivations (Emizet and Hesli 1995; Gurr and Moore 1997). But nationalists are not the only ones who discuss what form nations should take. Scholarly contributions have also argued that the size of nations may matter for a variety of policy outcomes. For instance, Alesina and Spoloare (2003) claim that the ideal size of states depends on security and economic concerns. In an uncertain international environment, large states appear to be a more attractive option, as they are more able to protect their citizens against foreign powers than small states. In economic terms, larger states have bigger markets and can take advantage of economies of scale. 
However, the emergence of the EU has removed many of these incentives to create large entities, and 'if there was ever an environment that favoured small states, surely it is modern Western Europe' (Griffiths et al. 2015). Firstly, the political stability and peace in most of Europe has meant that small nations do not fear being invaded by more powerful states.

Secondly, the creation of an integrated European economy with a single market and currency that guarantees the free movement of goods, capital, services, and people has reduced many of the negative economic externalities of being a small sovereign state. Existing evidence confirms that, besides having a pre-existing identity or a distinct language, relative affluence is a good predictor of secessionism (Sambanis and Milanovic 2011; Sorens 2005). Citizens of prosperous regions can develop the perception that they are being treated unfairly and that they would be economically better off if they had a state of their own (e.g. in cases of substantial imbalances in resources transferred by the region and public goods provided by the host state). Historically, rich regions were often compensated for negative imbalances by access to the host state's large market and its security umbrella. Since these arguments no longer apply in the EU context, it can be economically more attractive for prosperous stateless nations to leave the host state and become an independent EU Member State. Under these conditions, the stateless nation would neither suffer the loss of the market of its former host state for its products nor struggle with higher transaction costs if both the former host state and the new state would use the euro. Although the EU also has a system for indirect financial distribution between Member States that may create imbalances, the discrepancies are not as big as in most Member States. ${ }^{1}$ The political science literature has argued that economic expectations regarding secession can be an important factor to explain support for secession (Muñoz and Tormos 2014). Consequently, the prospect of social justice and redistribution of wealth within its own economy as an independent EU Member State can also be a strong argument for citizens to support secession from the host state.

\footnotetext{
${ }^{1}$ The exact transfer balances are a frequent matter of discussion in cases of secession, and the exact numbers depend heavily on the accounting methods applied. For example, according to the Spanish government the Catalan transfer imbalance with the Spanish state is about 8.5 billion Euros, whereas the Catalan government talks about 11.1 or 15 billion Euros (according to the method of calculation) (La Vanguardia 2014a). Finland, whose gross domestic product is roughly comparable to Catalonia, received in 2013 about 603 million Euros less from the EU coffers as it had contributed to the budget (European Commission 2015).
} 
Besides these economic motivations, the EU's current institutional structure may reinforce the political argument for secession. Since the decline of the concept of a 'Europe of the regions' some politicians of stateless nations have complained that they are not adequately represented in the corresponding decision-making mechanisms and that regional interests are not sufficiently taken into account (Hepburn 2008). Most power is still in the hands of the Member States through institutions such as the Council of the EU; and the European debt crisis further promoted the creation of new intergovernmental structures that now hold considerable power over the economic and financial policies of the Eurozone countries. Secessionist parties in EU Member States argue that only statehood guarantees a defence of their nation's interests within the EU institutions.

Due to these incentives the majority of Western Europe's most influential secessionist parties have developed arguments that seek to harmonise national sovereignty with transferring powers to Brussels. Moreover, in many cases this endorsement is also a strategic decision as European integration 'undermines the traditional identity among sovereignty, territory, nationality, and function that is the essence of the traditional nation-state and opens the way to other conceptions of political authority and of public action' (Keating 2004: 368). In Scotland, many Scottish nationalists are not so much convinced Europhiles as instrumental Europeans: being pro-European has become a way of creating a more favourable political opportunity structure for their autonomy aspirations (Jolly 2007).

Several secessionist groups have also incorporated a pro-European sentiment as part of the national identity. In Catalonia, embracing a European identity has become a way of contrasting a supposedly more modern and progressive character with the Spanish state, which is seen as conservative and isolationist. Being European is thus a synonym for modernity, and the Catalan nationalist discourse is sometimes based on the idea that 'we are not Spanish and we are better, because more modern, than they are' (Díez Medrano 2010: 18). Somewhat similarly, being proEuropean is for Scottish nationalists also a way of distinguishing Scotland from a more Eurosceptic England. Europe is thus not perceived as a threat to the nation's identity but as a useful instrument because the 'choice for Europe is a choice against the state identity, another form of assertion of the regional identity that is central to this people' (Díez Medrano 2010: 17). 
The EU may stimulate support for secessionism, but its accession rules can also act as a substantial stumbling block for the act of secession. The political and economic incentives mentioned above apply only if the newly independent entity is an EU Member State. However, the legal status quo, as repeatedly stated by the European Commission (Fariza 2014; Syal 2014) and similarly supported by various legal scholars (Borgen 2010: 1026; Chamon and Van der Loo 2014; Piris 2015), is that a newly independent region would, by the fact of its independence, become a third country with respect to the Union, and the treaties would, from the day of its independence, not apply anymore on its territory. Consequently, the new state would have to reapply for membership, and it would need the positive vote of all current Member States (including the former host state). In theory, the new state would be excluded from the Single Market and the Eurozone institutions during the transition years and would be prone to considerable political and economic instability.

It is impossible to predict how political actors will react to a real case of secession within the EU and how existing treaties will be interpreted. An alternative to a possible veto would be an 'internal accession process' by which EU membership would be negotiated in parallel with the necessary steps for sovereign independence after a successful referendum (Chamon and Van der Loo 2014: 628). But a priori this situation considerably limits the room for manoeuvring on the part of the seceding region, as it rules out almost all options for a declaration of independence without an agreement with the former host state. As long as the former host state denies recognising the new state, the route to EU membership remains closed. Expectedly, European host states with secessionist regions (e.g. Spain) are likely to ignore issues of democratic legitimacy and idealistic principles and pursue their short-term political calculations, especially in times of geopolitical upheaval (Qvortrup 2012).

To sum up, the current structure of the EU sends mixed signals to stateless nations in Europe: on the one hand, there are several political and economic incentives to become an independent Member State, but on the other hand it is virtually impossible to reach this status without the approval of the current host state.

\section{Hypotheses}


The potential accession to the EU and the possible exclusion from this political community may constitute powerful arguments in influencing the support for independence in a European stateless nation. The issue of EU membership was used by both the unionist executives of the UK and Spain as well as by secessionist leaders in Scotland and Catalonia in trying to persuade their electorate. More specifically, secessionists tried to reassure their pro-European supporters by telling them that their new state would continue to be part of the EU. Based on the described political and economic advantages of being a small, prosperous EU Member State, our first hypothesis reads as follows:

H1: The incentive of inclusion in the EU will have a positive effect on the support for secessionism.

However, as also described, these membership advantages can only be enjoyed if the new state can smoothly enter the EU. If there is a lengthy process of negotiation in which the stateless nation transitions from being a region to a sovereign state, this can come hand in hand with political and economic instability and uncertainty. Member States and other proponents of the status quo are likely to use such doom scenarios about the region's future as arguments against steps towards secession. For this reason, more risk-averse voters are likely to stay away from an unpredictable scenario. Hence, our second hypothesis proposes a scenario where being outside the EU weakens the secessionist campaign:

$\mathrm{H} 2$ : The threat of exclusion from the EU will have a negative effect on the support for secessionism.

Besides testing these two hypotheses, we also want to examine what variables might moderate or mediate the relationship between possible EU inclusion/exclusion and support for secession. ${ }^{2}$ We therefore formulated two additional hypotheses to identify these possible mechanisms.

Firstly, we expected the degree of nationalism of the respondents to be a decisive factor. Nationalism, as defined by Anthony D. Smith (1991: 73), is 'an ideological movement for attaining and maintaining autonomy, unity and identity on behalf of a population deemed by

\footnotetext{
${ }^{2}$ Treatment moderators specify for whom or under what conditions the treatments works (Kraemer et al. 2002); treatment mediators identify possible mechanisms through which a treatment might achieve its effects. These mechanisms are causal links between treatment and outcome.
} 
some of its members to constitute an actual or potential "nation". The idea of a distinct nation with a regional cultural or particular ethno-history within a different host state neither leads to identity politics nor separatism, for there are also plenty of nations that are satisfied with the status quo and only seek incremental political change. However, ever-growing sections of the Scottish and Catalan populations have grounded their political arguments on their - perceived shared experiences of injustice at the hands of their host states. The fact that people's politics are shaped by their identity suggests that the degree of sub-state nationalism will be an indicator of support for the secessionist agenda (Hechter 1992). Confronted with a dichotomous choice -secession or union - we expect Catalan/Scottish nationalist respondents therefore to have stable preferences that cannot be completely transformed by the treatments. For the same reasons, we also expected individuals that support Spanish/British nationalism to be less influenced by the external treatments. Similarly, less nationalist individuals will be more influenced by the treatments as they had less fixed preferences regarding this dichotomous choice. Our third hypothesis was therefore:

H3: The stronger (weaker) the level of nationalism in the individual, the less (more) he/she will be influenced by the information about the prospect of EU inclusion/exclusion.

Secondly, we wanted to test to what extent the general assessment of the EU might mediate the relationship between our treatments and the support for secession. In times of growing 'protest populism' and declining responsiveness of EU institutions during the Great Recession, it was not self-evident that all citizens would perceive exclusion from the EU as a threat or negative outcome and EU membership as a positive incentive (Kriesi 2014). Hence, we expected individuals with a positive idea of the EU to be more influenced by information about possible EU inclusion/exclusion than individuals with a more critical view of the EU. Openly anti-EU individuals could even experience these treatments in an opposite way and see a possible exclusion from the Union as an incentive to support secession. We followed the Eurobarometer in operationalising the general assessment or image of the EU by asking our respondents directly how much they trusted the Union. Therefore, our fourth statement hypothesised that:

H4: The more (less) trust an individual has in the European Union, the more (less) he/she will be influenced by the information about the prospect of EU inclusion/exclusion. 
To recapitulate, the aim of the survey experiment was to examine whether providing individuals with new information about the prospects of EU membership could affect an individual's political preferences for secession. The next section explains the design of the online experiment used to test the influence of international factors on domestic support for secessionism in Catalonia and Scotland.

\section{Survey Experiment}

In order to test the four hypotheses, we gathered data using a web-based survey experiment in both Catalonia and Scotland. We selected these two case studies because they share a somewhat similar configuration, which makes it possible to control for key variables. Both stateless nations were part of the EU, were relatively prosperous (Scotland due to its oil reserves), and both had vigorous secessionist movements at the time the survey was deployed, not to mention the fact that both had scheduled a referendum on independence.

The Catalan and Scottish cases shared analogous perceptions, interpretations, and aspirations for home rule, but there were also important differences, such as the fact that Spain belongs, in contrast to the UK, to the Eurozone. Moreover, whereas the referendum in Scotland was agreed upon with the British government, the referendum in Catalonia was scheduled by the regional government with neither negotiation nor legal recognition by the Spanish executive. ${ }^{3}$ For the interpretation of our findings it was therefore important to take these different starting points into account. In the case of Catalonia, high-ranking EU officials have declared that an independent Catalan state that seceded unilaterally would automatically be excluded from the EU for an undefined time (Ayadi et al. 2015: 36). The EU's suggestion to find a negotiated solution to the conflict suited the position of the Spanish government, who clearly preferred the status quo. In Scotland, the Better Together camp warned about a difficult accession process but did not deny the principal possibility of a Scottish EU membership (Morris 2014).

In short, this historical setting provided us with the opportunity to test our hypotheses about the role of EU membership in a genuine background, in which the questionnaire on

\footnotetext{
${ }^{3}$ The lack of agreement on the Catalan referendum, also known as 'citizen participation process on the political future of Catalonia', led to its suspension by the Spanish Constitutional Court.
} 
political independence would not appear unrealistic to respondents, as both Scots and Catalans went to the polls months after the survey experiment was held. At the same time, potential problems of contamination and pre-priming made essential the inclusion of a control group.

The goal of the survey experiment was to study whether citizens would change their preferences for self-government if they were exposed to hypothetical scenarios concerning EU inclusion/exclusion following political independence. After being confronted with the vignette, the participants were asked how they would vote in a referendum if this scenario were true. ${ }^{4} \mathrm{We}$ decided to administer the survey a week before the European parliamentary elections of 22 May 2014, in order to maximise the respondents' knowledge of European issues and debates. The samples for Catalonia and Scotland were of approximately 1,200 respondents in each case, and we divided these two samples into three representative subgroups of 400 individuals in terms of age, gender, level of education, and place of residence. All groups were confronted with an identical questionnaire of 38 questions in various languages. In Catalonia, this meant that respondents were offered the possibility of answering in either Catalan or Spanish. ${ }^{5}$ A survey firm with ample experience in commissioning national and international representative surveys administered the experiment. A more detailed explanation of the technical characteristics of the survey can be found in the annex.

The experiment's dependent variable was conceptualised as 'support for secession'. We operationalised the dependent variable by asking the scheduled referenda questions to the respondents of our web-based survey experiment. Whereas the referendum question in Scotland was rather straightforward ('Should Scotland be an independent country? Yes or No?'), the design of the Catalan question was more convoluted with two subsequent questions that gave Catalan voters the options to vote (I) against any changes of the status quo, (II) in favour of a non-independent state (whatever form that might take), or (III) in favour of an independent state. ${ }^{6}$

\footnotetext{
${ }^{4}$ Needless to say, an obvious disadvantage to this sort of experiment is that a vignette is different from experiencing a real stimulus in everyday life and that the results obtained are estimates, which cannot be validated.

${ }_{5}^{5}$ The complete list of questions and vignettes (in Catalan. English and Spanish) and answers can be downloaded from our website: XXXXXX.

${ }^{6}$ In the Catalan referendum, the voters were first supposed to answer a question: 'Do you want Catalonia to become a State?' In the affirmative case, the voters also had the opportunity to respond to the question 'Do you want this State to be independent?' So, in sum, the Catalan voters had three options: voting in favour of an independent state
} 
We expected that the scenario or treatment would only play a role in the case whether Catalonia aspired to become an independent state. For our model we thus lumped (I) and (II) together to create - as in the Scottish case - a dichotomy of secessionists and unionists.

Each subgroup received different 'new information' about the international future of an independent Catalonia or Scotland. These treatments were placed after an initial round of sociodemographic questions, which were then used as control variables. The first subgroup was confronted with a 'positive' scenario where accession to the EU seemed likely. In both Catalonia and Scotland, the respondents were asked how they would vote in a referendum under the following circumstances:

Before the referendum on the independence of Catalonia(/Scotland), the EU authorities and the Member States issue a statement saying that if the majority of Catalans(/Scots) vote in favour, the new Catalan(/Scottish) state can be a member of the EU from its first day of independence.

Our second subgroup was confronted with a 'negative' scenario concerning the membership prospects of the two regions. In order for the respondents to encounter plausible scenarios, we had to modify the vignettes slightly so there would be no rejection on the part of respondents. The Catalan respondents were confronted with the following information:

Before the referendum on the independence of Catalonia, the EU authorities and the Member States issue a statement saying that, regardless of the result, Catalonia has no prospect of joining the EU.

In the case of Scotland where the debate was less polarised the respondents received the following treatment:

Before the referendum on the independence of Scotland, the EU authorities and the Member States issue a statement saying that an independent Scotland has no prospect of joining the EU automatically and that it will have to re-apply for membership and go through the full accession process.

A third control group did not receive any hint of an outcome and was used as a reference group in order to measure whether the positive and negative suggestions had any effect. This

(Yes-Yes); voting in favour of a state, which is not independent (Yes-No), or voting against the entire idea of a Catalan state (No). 
control group made it possible to measure the variation between the control subgroup and the positive and negative subgroups as well as measure the impact of the vignettes.

In order to measure the effect of the treatments, we created a model that included also a series of control variables (see Table 1 in appendix). In this model we also included the respondents' gender, age, place of residence, education level, income level, language spoken at home (in the case of Catalonia), national self-identification, and their trust in the EU.

As it is standard practice in public opinion surveys, we used the participants' selfidentification in terms of national belonging to measure the respondent's degree of nationalism (Centre d'Estudis d'Opinió 2015: 39; Scottish Referendum Study 2014: 18). Both in Catalonia and in Scotland, nationalist leaders promote in public a 'civic nationalism', that is in principle open to individuals who came to the region from the rest of Spain/the UK (Mycock 2012; Serrano 2013). We asked the respondents the so-called 'Linz question', which is a popular measure of regionalism in Europe and has been previously used in studies on Catalonia and Scotland (Moreno 2006). The respondents could classify themselves (e.g. in the case of Scotland) as feeling 'Only Scottish', 'Only British' (which we classify as exclusive identities), 'More Scottish than British', 'More British than Scottish', (dual identities) and 'Both Scottish and British' (shared identities). ${ }^{7}$

In order to measure the respondents' trust in the EU, we asked them 'How much trust do you have in the EU on a scale from 0-10? 0 is having no confidence and 10 is having complete confidence.' Besides the EU the participants were also expected to rank the Spanish/British Parliament and government and the Catalan/Scottish Parliament and government.

\section{Results and Discussion}

The goal of our web-based survey experiment was to test the extent to which support for secession could be mediated by the incentive of EU membership (both positive and negative). In order to measure the impact of international threats and payoffs on the respondents' support for secession, we estimated the average treatment effect (ATE), a parameter that measures the difference in mean outcomes for treated and untreated units. The expression 'treatment effect' is

\footnotetext{
${ }^{7}$ A small and very heterogeneous group of respondents choose the option 'Other'.
} 
basically the difference between an outcome variable of interest (in our case, support for independence) for individuals who were exposed to the treatment and individuals who were allocated to the control group (a more detailed table can be found in Appendix 1).

With regards to our expectations, the results of the survey experiment supported the first hypothesis (H1: The incentive of inclusion in the EU will have a positive effect on the support for secessionism). As can be observed in Table 1, controlling for all the other variables included in the model, the offer of a smooth EU accession process after secession rendered a positive and significant treatment effect on support for secessionism in Catalonia. After being confronted with the prospect of direct EU inclusion, it was more likely that a respondents said that he/she would vote in favour of secession in a referendum. In Scotland, the positive intervention increased the likelihood for voting in favour of independence but not on a statistically significant level.

\section{[TABLE 1 HERE]}

Our second hypothesis (H2: The threat of exclusion from the EU has a negative effect on the support for secessionism) could not be confirmed by the randomised trial. Whereas in Catalonia we could detect a small decline in support for secession, the pro-independence camp in Scotland gained even more support when primed with a negative treatment of EU exclusion. Although this result was not statistically significant, we will discuss it below in more detail.

It is our understanding that the rejection of $\mathrm{H} 2$ does not necessarily mean that threats concerning possible EU exclusion were unimportant in real life. As a matter of fact, the refutation of our second hypothesis can be explained by the fact that host states had adopted dominant strategies that emphasised the scenario of a lengthy accession process (in the best of cases), which amounted to priming the populations with a negative scenario. As can be seen in Figure 1, the results for the neutral and negative groups were similar because citizens had already been exposed to a scenario of EU inclusion and did not perceive the negative treatment as 'new' information. 
The Spanish public debate on EU membership was dominated by catastrophic scenarios where Madrid and other European capitals would veto a hypothetical Catalan application, and Brussels would consequently refuse to fast track any membership application. For instance, Spanish Foreign Minister García-Margallo warned that a unilateral declaration of independence would condemn Catalonia to 'wander through space without recognition and to be excluded from the EU for ever and ever' (La Vanguardia 2014b). ${ }^{8}$ The Spanish government also indicated its willingness to use all available legal means and to even amend existing laws in order to prevent Catalonia from seceding and keep Spain together (Gutiérrez Calvo 2014). The Scottish political context was different, but while Westminster did not make explicit threats of vetoing a possible Scottish application to the EU, Prime Minister Cameron warned Scotland that it 'would have to queue up behind other countries (...) that [were] already on the path towards membership' (Morris 2014).

In short, it could be argued that the 'negative scenario' did not have any effect on respondents because they had already been exposed to a negative treatment in real life and did not consider the scenario as 'new information' that could change their preferences for a sovereign state. That might explain why the effects of the negative vignette are similar to the results obtained in the control group. Nevertheless, the positive vignette that assured a smooth integration in the EU was a 'game-changer' and caused, at least among our respondents in Catalonia, a very significant impact. For the other instances, the argument of EU inclusion did not produce dramatic changes that could have determined the outcome of a hypothetical referendum at that point.

In our third and fourth hypothesis, we sought to zoom in on the motivations of our respondents for their choice. With our third hypothesis (H3: The stronger (weaker) the level of nationalism in the individual, the less (more) he/she will be influenced by the information about the prospect of EU inclusion/exclusion) we wanted to test the extent to which the degree of nationalism could mediate the impact of our treatments. Our assumption was that national identity was the main driver of secession, and we expected identity to be an important mediating

\footnotetext{
${ }^{8}$ In Spanish: A unilateral declaration of independence 'condenaría (Cataluña) a vagar por el espacio sin reconocimiento y a quedar excluida de la Unión Europea por los siglos de los siglos'.
} 
variable (see Table 1 in the appendix). Before we proceed to discuss the power of identity in mediating the impact of our treatments, it is important to point out that very few respondents identified exclusively or predominantly with 'Spain' or 'Britain'. Consequently, we followed the work of Rico and Jennings (2012: 729) in lumping together the answers of two groups of respondents: those who felt more 'Spanish than Catalan' with 'Only Spanish' and 'British than Scottish' with 'Only British'. In order to study the vignette's impact on the four sub-groups, we measured the average marginal effects of the treatments.

As can be seen in Figure 2, Catalan respondents behaved in accordance to our hypothesised expectations that more nationalist individuals were less likely to be influenced by the treatments. The preferences of the respondents who identified exclusively as Catalans or predominantly/exclusively as Spaniards were not radically altered. However, respondents who defined themselves as more Catalan than Spanish or as equally Catalan and Spanish were considerably more influenced by the positive treatment (the negative treatment did not produce comparable results on any sub-group in Catalonia).

[FIGURE 2 HERE]

The Scottish results did not confirm our third hypothesis. The positive treatment influenced all sub-groups to a statistically significant level but had most impact on the respondents who felt exclusively Scottish. Even more surprising was the finding that the negative treatment increased support for secession among respondents who felt exclusively or predominantly Scottish.

One possible explanation for this paradox could be the fact that respondents who felt predominantly or exclusively Scottish were even more determined to vote in favour of independence after the threat of exclusion had been issued. According to surveys during the 2014 campaign, a similar act of defiance took place when the Tory government tried to nudge Scottish voters to vote in support of the Union. The Better Together campaign backfired, arguably for its dispassionate lack of concrete proposals for constitutional change, and the secessionist camp was consequently strengthened (Watt 2014). 
In order to evaluate the explanatory power of nationalism, we devised an additional test designed to capture the political dynamics at a micro level. The survey experiment asked participants to self-evaluate the extent to which they had been affected by the treatments. ${ }^{9}$ Figure 3 provides a visualisation of the effects, where the $y$ - displays the impact of the option (ranging from 1 [nothing] to 5 [a lot]), and the x-axis distinguishes respondents by national selfidentification.

[FIGURE 3 HERE]

Although the limitations of self-evaluations are clear, we can say that the data for both cases further reinforces our third hypothesis. The respondents with the highest degree of substate nationalism (feeling exclusively Catalan or Scottish) indicated that they were only moderately influenced. Similarly, the respondents with the highest degree of state nationalism, who identified exclusively or predominantly with the host state, stated that the treatments had only moderately affected their choice. According to our results, participants with a somewhat lower level of sub-state nationalism (as indicated by their dual identities) felt more influenced by the treatments than those respondents with the highest level of sub-state nationalism. This finding is in agreement with scholars who argue that the future of Spain or the UK as presently constituted lies in the hands of those with multiple identities. In the case of Scotland, Bechofer and McCrone (2010) have proven that those who describe themselves as equally national (English or Scottish) and British put an emphasis on devolution whereas those with exclusive identities favour secession or holding the UK as a single state. From the point of view of secessionists, the model of dual self-identification is a stumbling block against the creation of strong majorities for independence. Only when citizens of the stateless nation identify themselves in an exclusive manner will the institutional outcome of their antagonism with the state also be exclusive (Keating 2000). Finally, respondents with a shared identity and feelings of attachment to both the stateless nation and the host state were the individuals who acknowledged

\footnotetext{
${ }^{9}$ The exact question was 'You would vote in favor of (against) independence. To what extent would membership of the EU influence your decision?' The respondents could choose between the following options: (1) Nothing, (2) Almost nothing, (3) Some, (4) Quite a lot, and (5) A lot.
} 
most that they had taken into account the international dimension when making a decision in our survey in favour of or against independence.

In sum, the respondents' degree of nationalism played a substantial role in mediating the effect of the treatments. In Catalonia, the individuals with shared or dual identities were especially influenced by both the 'threat' and 'payoff' scenarios. The results from Scotland were also consistent except for the case of Scottish nationalists who were, contrary to our expectations, most influenced by the treatments. When taking the respondents' self-evaluation into account, the hypothesis gets some additional support: individuals with exclusive identities said that they had been less influenced by the vignettes about an EU membership than individuals with shared identities.

With the fourth and final hypothesis (H4: The more (less) trust an individual has in the European Union, the more (less) he/she will be influenced by the information about the prospect of EU inclusion/exclusion) we wanted to test to what extent the respondents' trust in the EU would mediate the effect of the treatment. In short, our expectation was that individuals who evaluated the EU positively were more likely to be affected by a changing scenario regarding the membership of their future country. By contrast, respondents with a negative attitude towards the EU were expected to be either indifferent to the treatments or, if they held very anti-European views, to consider the threat of EU exclusion as an additional argument to support secession and gain some distance from the EU.

[FIGURE 4 HERE]

Figure 4 displays the impact of the treatments on the likelihood to vote in favour of independence by trust in the EU. The positive incentive of EU inclusion predictably increased support for secession in both Catalonia and Scotland (as this was an option that offered lower transaction costs), but the degree of trust that the participants had in the EU did not play a major role. Hence the part of the hypothesis that refers to the positive priming could not be confirmed. By contrast, the results of the negative treatment confirmed our expectations in two ways. 
First, respondents who acknowledged high trust in the EU were less likely to support statehood for their nation after the negative treatment. As can be seen in Figure 4, the individuals who were part of the negative experiment displayed a clear negative relationship between trust in the EU and the probability of voting for independence. The Catalan group displayed a greater slope, whereas the Scottish line was less neat yet showed the same tendency.

Second, respondents who displayed low trust in the Union embraced the prospect of EU exclusion, and among these participants support for independence even grew after a negative treatment. For these Eurosceptic participants the negative priming was not understood as a threat but as an incentive to vote in favour of independence. This phenomenon also partly explains the different effects of the negative treatments in Catalonia and Scotland. As previously explained, Catalan voters are in tendency more profound Europhiles, while Scottish voters are more instrumental Europeans. In Catalonia about 32 percent of the respondents fell in the category of participants among which the likelihood of support for secession grew after the negative treatment (those respondents whose trust in the EU in Figure 4 has a value of 3 or lower). In Scotland, however, about 70 percent of the respondents belonged to that group (respondents whose trust in the EU in Figure 4 has a value of 5 or lower).

The positive treatment did not have a similar effect because it was not a game-changer for Eurosceptics: voting 'Yes' to independence would mean an independent Scotland/Catalonia in the EU, and voting 'No' would mean remaining in the EU as part of the current host state. Consequently, only their preferences on the secession issue defined their choice.

\section{Conclusion}

This paper has examined whether possible EU inclusion/exclusion could affect domestic support for secession in stateless nations. We assumed that the EU's institutional structure has created incentives for stateless nations to seek independence, provided that a smooth integration in the Union can be guaranteed. For this reason, we thought that the number of voters supporting secession would increase if they were given assurances that the accession process would have low transaction costs. On the other hand, we expected that voters would refrain from supporting the secessionist agenda if the political and economic integration of the new state into the EU 
could be a lengthy and unclear process. The on-line survey experiment in Catalonia and Scotland partially confirmed the importance of EU membership in shaping secessionist preferences.

In Catalonia, the positive treatment (likely EU membership) had a significant effect, while the effect of the negative treatment (possible EU exclusion without a membership prospect) was more limited. We explain this difference by making reference to the political context in which the survey was conducted. Opponents of secession, the Spanish government, and the EU institutions had signalled threats about an undetermined exclusion from the EU, and individuals had therefore already incorporated them in their calculations. The positive scenario turned out to be a 'game changer', whereas the negative one only confirmed the assumed status quo for many respondents. We argue that this is the main reason why the results of the control group and the 'negative' group were remarkably similar.

The results in Scotland were less clear-cut: neither the positive treatment (an immediate EU membership for an independent Scotland) nor the negative treatment (Scotland would have to reapply for EU membership) had a statistically significant effect. Support for secession increased somewhat after our positive vignette but also after our negative vignette, an effect that could be explained by the Euro-scepticism of some voters.

The second key finding is that the sanctions and incentives did not affect populations homogenously. The preferences for secession were determined at the domestic level and often depended on the degree of nationalism of individuals. Respondents with strong nationalist selfidentification - towards the stateless nation or the host state - were moderately influenced by the treatments. Respondents with dual or shared identities, however, were more likely to change their vote when primed about EU membership. Evaluating the average marginal effects of the treatments gave us mixed results, but an additional test based on the self-evaluation of respondents confirmed our expectations. Participants with shared identities in both regions selfreported that they had been greatly affected by the treatments, a result that was much more moderate for those participants holding exclusive identities.

The third key finding is that trust in the EU was a factor mediating the views of respondents to scenarios of EU inclusion/exclusion. The expectation was that respondents who held a positive idea of the EU would be more influenced by the treatments than the rest of the population. By contrast, respondents with a negative attitude towards the EU would be either 
indifferent to the treatments or would be encouraged to support secession (in order to distance themselves from the EU). The results of the positive treatment for Catalonia and Scotland are very similar, but the truly interesting finding concerns individuals who were part of the negative treatment group. Pro-EU respondents who were threatened with EU exclusion were clearly less likely to vote for independence. Similarly, respondents who did not trust the Union were not affected by the negative priming, and the threat of exclusion acted as an incentive for them to choose the pro-independence option.

In other words, Euroscepticism affected the two countries differently. The desire to slow down European integration is absolutely marginal in Catalonia, and political elites have never articulated the need to vote for secession as a means to leave the EU. However, in Scotland, for a share of the population, the prospect of leaving the EU is not a threat but an incentive to vote 'Yes' in a referendum.

With regard to policy implications, the research findings presented here resonate with current developments in EU Member States. Politicians of host states have sometimes resorted to international threats with the aim of intimidating supporters of secession. Our findings demonstrate that political preferences are predominantly formed at the domestic level and only to limited extent altered by threats, such as blocking EU membership. The issue of future EU membership can perhaps tip the scale in a close race by convincing or discouraging individuals with shared identities and pro-EU attitudes. But threats can even backfire, as in Scotland, and motivate more Eurosceptic citizens to opt for independence. In sum, both proponents and/or opponents of secession should not regard EU membership as a 'silver bullet' that can dramatically alter the votes of the majority of the population.

\section{$\underline{\text { Technical annex }}$}

Geographical scope: Autonomous Community of Catalonia (Spain) and Scotland (United Kingdom). Universe: individuals residing in the area of study older than 18.

Size and distribution of sample: 1,203 interviews in Catalonia, 1,205 interviews in Scotland. The respondents were divided into representative sub-groups of 400 individuals, applying the age, gender and place of residence quotas (in Catalonia: Provinces; in Scotland: Council Areas). 
Sampling error: for a confidence level of $95.5 \%$ (which is usually adopted) and assuming the principles of simple random sampling, in the worst case scenario of maximum uncertainty $(p=q$ $=50 \%$ ), the sampling error corresponds to the data on the total sample is 3.2 points. Method of collecting information: online survey, using structured and pre-coded questions. The task has been carried out by Netquest, using their databank of respondents. The questionnaire was available in Spanish and Catalan (Catalonia) or English (Scotland). Date of fieldwork: May 2014.

\section{$\underline{\text { References }}$}

Alesina, Alberto and Enrico Spolaore (2003). The Size of Nations. Cambridge (MA): MIT Press.

Ayadi, Rym; Leonidas Paroussos; Kostas Fragkiadakis; Stella Tsani; Pantelis Capros; Carlo Sessa; Riccardo Enei and Marc Gafarot (2015), Scenarios of Macro-economic Development for Catalonia on Horizon 2030. Barcelona: CIDOB. Available at: < http://www.cidob.org/content/download/61317/1858086/version/25/file/MONOGRAFIA\%20 CIDOB\%20SECESSION\%20SCENARIOS-Final\%20edited2.pdf > [Accessed 11 September 2015].

Bechofer, Frank and David McCrone (2010). 'Choosing National Identity', Sociological Research Online, 15:3.

Borgen, Christopher J. (2010). 'From Kosovo to Catalonia: Separatism and Integration in Europe', Goettingen Journal of International Law, 2:3, 997-1033.

Bourne, Angela K. (2014). 'Europeanization and Secession: The Cases of Catalonia and Scotland', Journal on Ethnopolitics and Minority Issues in Europe, 13:3, 94-120.

Caspersen, Nina (2011). Unrecognised States: The Struggle for Sovereignty in the Modern International System. Cambridge: Polity Press.

Centre d'Estudis d'Opinió (2015). 'Political Opinion Barometer - Questionnaire in English'. Available at: $\quad<$ http://ceo.gencat.cat/ceop/AppJava/loadFile?fileId=23713\&fileType=1> [Accessed 11 September 2015].

Chamon, Merijn and Guillaume van der Loo (2014). 'The Temporal Paradox of Regions in the EU Seeking Independence: Contraction and Fragmentation versus Widening and Deepening?', European Law Journal, 20:5, 613-629. 
Consell Assessor per a la Transició Nacional (2014). Paths for Catalonia's integration in the European Union. Available at: $<\mathrm{http}: / /$ presidencia.gencat.cat/web/.content/ambits_actuacio/consells_assessors/catn/informes _publicats/inf_6_angles.pdf $>$ [Accessed 11 September 2015].

Díez Medrano, Juan (2010). 'Unpacking European Identity', Politique européenne 30, 45-66.

Emizet, Kisangani N. and Vicki L. Hesli (1995). 'The Disposition to Secede: An Analysis of the Soviet Case', Comparative Political Studies, 27:4, 493-536.

European Commission (2015). 'EU expenditure and revenue - Operating budgetary balance (Finland)'. Available at: <http://ec.europa.eu/budget/figures/interactive/index_en.cfm> [Accessed 11 September 2015].

Fariza, Ignacio (2014). 'Bruselas insiste en que una Cataluña independiente quedaría fuera de la UE', El País, [online] (Last updated 2.34 PM on 15 April 2014). Available at: $<$ http://politica.elpais.com/politica/2014/04/15/actualidad/1397565276_232144.html $\geq[$ Access ed on 11 September 2015].

Garcia Pagan, Isabel (2015). 'El debate Margallo-Junqueras, un duelo de altura por Europa', $L a$ Vanguardia, [online] (Last updated 10.46 PM on 23 September 2015). Available at: < http://www.lavanguardia.com/politica/elecciones-catalanas/20150923/54435445966/debatemargallo-junqueras-duelo-altura-europa.html $\geq$ [Accessed on 29 September 2015].

Griffiths, Ryan D.; Pablo Guillén Álvarez and Ferran Martínez i Coma (2015). 'Between the Sword and the Wall: Spain's Limited Options for Catalan Secessionism', Nations and Nationalism, 21:3, 43-61.

Gurr, Ted R. and Will H. Moore (1997). 'Ethnopolitical Rebellion: A Cross-Sectional Analysis of the 1980s with Risk Assessments for the 1990s', American Political Science Review, 41:4, 1079-1103.

Gutiérrez Calvo, Vera (2014). 'El estado prepara su batería jurídica', El País, [online] (Last updated $1.42 \mathrm{AM}$ on 4 October 2014). Available at: $<$ http://politica.elpais.com/politica/2014/10/03/actualidad/1412360528_424103.html $\geq$ [Accessed on 11 September 2015].

Hechter, Michael (1992). 'The Dynamics of Secession', Acta Sociologica, $35: 4,267-283$. 
Hepburn, Eve (2008). 'The Rise and Fall of a 'Europe of the Regions", Regional \& Federal Studies, 18:5, 537-555.

HM Government (2014). Scotland analysis: EU and international issues. Available at: $<$ https://www.gov.uk/government/uploads/system/uploads/attachment_data/file/271794/2901475 _HMG_Scotland_EUandInternational_acc2.pdf $>$ [Accessed 11 September 2015].

Jolly, Seth K. (2007). 'The Europhile Fringe? Regionalist Party Support for European Integration', European Union Politics 8:1, 109-130.

Keating, Michael (2004). 'European Integration and the Nationalities Question', Politics \& Society 32:3, 367-388.

Keating, Michael (2010) The Independence of Scotland. Self-government \& the Shifting Politics of Union. Oxford: Oxford University Press.

Ker-Lindsay, James (2012). The foreign policy of counter secession: Preventing the recognition of contested states. Oxford: Oxford University Press.

Kraemer, Helena Chmura; G. Terrence Wilson; Christopher G. Fairburn and W. Stewart Agras (2002). 'Mediators and Moderators of Treatment Effects in Randomized Clinical Trials', Archives of General Psychiatry, 59:10, 877-883.

Kriesi, Hanspeter (2014). 'The Populist Challenge', West European Politics, 37:2, 361-78.

La Vanguardia (2014a). 'El déficit fiscal de Catalunya es de 8.455 millones según las balanzas del Gobierno', La Vanguardia, [online] (Last updated: 2.28 PM on 25 July 2014). Available at: <http://www.lavanguardia.com/politica/20140723/54412386000/deficit-fiscal-catalunya-8455-milllones.html $>$ [Accessed on 11 September 2015].

La Vanguardia (2014b). "Margallo afirma que Catalunya "vagaría por el espacio" si se independiza', La Vanguardia, [online] (Last updated: 6.09 PM on 10 March 2014). Available at: <http://www.lavanguardia.com/politica/20140310/54402947586/margallo-una-catalunaindependiente-estaria-excluida-de-la-ue-durante-siglos.html $>$ [Accessed on 11 September 2015].

Moreno, Luis (2006). 'Scotland, Catalonia, Europeanization and the 'Moreno Question", Scottish Affairs, 54, 1-21.

Morris, Nigel (2014). 'Scottish independence: Scotland 'would be put at the back to the queue to join EU' says David Cameron', The Independent, [online] (Last updated 3 June 2014). 
Available at: $\quad<$ http://www.independent.co.uk/news/uk/politics/scottish-independencescotland-would-go-to-the-back-to-the-queue-to-join-eu-says-david-cameron-9475319.html> [Accessed on 11 September 2015].

Muñoz, Jordi and Raül Tormos (2015). 'Economic expectations and support for secession in Catalonia: between causality and rationalization', European Political Science Review, 7:2, 315-341.

Mycock, Andrew. (2012). 'SNP, identity and citizenship: Re-imagining state and nation', National Identities, 14:1, 53-69.

Piris, Jean-Claude (2015). 'Cataluña y la Unión Europea', El País, [online] (Last updated 12.00 AM on 29 August 2015). Available at: $<$ http://elpais.com/elpais/2015/08/28/opinion/1440759431_272426.html> [Accessed on 11 September 2015].

Syal, Rajeev (2014). 'Independent Scotland 'would find it extremely difficult to join EU', The Guardian, [online] (Last updated 1.52 PM on 16 February 2014). Available at: $<$ http://www.theguardian.com/politics/2014/feb/16/independent-scotland-extremely-difficultjoin-eu> [Accessed on 11 September 2015].

Qvortrup, Matt (2012). 'The history of ethno-national referendums 1791-2011', Nationalism and Ethnic Politics, 18:1, 129-150.

Rico, Guillem and M. Kent Jennings (2012). 'The Intergenerational Transmission of Contending Place Identities', Political Psychology, 33:5, 723-742.

Sambanis, Nicholas and Branko Milanović (2011). Explaining the Demand for Sovereignty. [pdf] Washington DC: World Bank Policy Research Working Paper, no. 5888. Available at: $<$ http://elibrary.worldbank.org/doi/pdf/10.1596/1813-9450-5888> [Accessed 11 September $2015]$.

Serrano, Ivan (2013). 'Just a Matter of Identity? Support for Independence in Catalonia', Regional \& Federal Studies, 23:5, 523-545.

Scottish Government (2014). Scotland's Future - Your Guide to an Independent Scotland, Available at: <https://www.scotreferendum.com/reports/scotlands-future-your-guide-to-anindependent-scotland/> [Accessed 11 September 2015]. 
Scottish Referendum Study (2014). 'SRS 2014 pre-referendum questionnaire'. Available at: $<$ http://www.scottishreferendumstudy.com/files/2015/01/SRS-pre-wave.docx $>$ [Accessed 11 September 2015].

Smith, Anthony D. (1991). National Identity. London \& New York: Penguin Books.

Sorens, Jason (2005). 'The Cross-Sectional Determinants of Secessionism in Advanced Democracies', Comparative Political Studies, 38:3, 304-326.

Spanish Ministry of Foreign Affairs and Cooperation (2013). Cataluña en España. Por la convivencia democrática. Available at: < http://www.exteriores.gob.es/Portal/es/SalaDePrensa/Multimedia/Publicaciones/Documents/P orlaconvivencia/POR\%20LA\%20CONVIVENCIA\%20DEMOCRATICA.pdf> [Accessed 11 September 2015].

Watt, Nicholas (2014). 'Scottish independence: currency union warning 'backfires' on Westminster', The Guardian, [online] (Last updated 2.56 PM on 20 February 2014). Available at: <http://www.theguardian.com/politics/2014/feb/20/scottish-independencecurrency-union-warning-backfires> [Accessed on 11 September 2015].

\section{$\underline{\text { Appendix }}$}

\section{APPENDIX 1: LOGISTIC REGRESSION MODEL FOR SUPPORT FOR INDEPENDENCE}

\begin{tabular}{|c|c|c|c|c|c|c|}
\hline & \multicolumn{3}{|c|}{ Catalonia } & \multicolumn{3}{|c|}{ Scotland } \\
\hline & (1) & $(2)$ & (3) & (4) & $(5)$ & (6) \\
\hline VARIABLES & M1 & M2 & M3 & M4 & M5 & M6 \\
\hline $\begin{array}{l}\text { Positive treatment } \\
\text { (compared to control } \\
\text { group) }\end{array}$ & $\begin{array}{c}0.642 * * \\
(0.269)\end{array}$ & $\begin{array}{c}0.423 \\
(0.577)\end{array}$ & $\begin{array}{c}0.631 \\
(0.829)\end{array}$ & $\begin{array}{c}0.296 \\
(0.180)\end{array}$ & $\begin{array}{c}0.562 * * \\
(0.271)\end{array}$ & $\begin{array}{c}0.637 \\
(0.409)\end{array}$ \\
\hline $\begin{array}{l}\text { Negative treatment } \\
\text { (compared to control } \\
\text { group) }\end{array}$ & $\begin{array}{c}-0.0564 \\
(0.267)\end{array}$ & $\begin{array}{l}-0.750 \\
(0.496)\end{array}$ & $\begin{array}{l}-0.120 \\
(0.763)\end{array}$ & $\begin{array}{c}0.223 \\
(0.181)\end{array}$ & $\begin{array}{c}1.089 * * * \\
(0.291)\end{array}$ & $\begin{array}{c}1.525^{* * * *} \\
(0.441)\end{array}$ \\
\hline $\begin{array}{l}\text { National identity } \\
\text { (compared to ‘Only } \\
\text { Catalan/ Only Scottish }\end{array}$ & & & & & & \\
\hline $\begin{array}{l}\text { More Catalan than } \\
\text { Spanish/ More Scottish } \\
\text { than British }\end{array}$ & $\begin{array}{c}-3.475 * * * \\
(0.731)\end{array}$ & & & $\begin{array}{c}-1.077 * * * \\
(0.199)\end{array}$ & & \\
\hline Equally Catalan and & $-5.930 * * *$ & & & $-2.765 * * *$ & & \\
\hline
\end{tabular}


Spanish/ Equally Scottish $\quad$ (0.750)

and British

More Spanish than

Catalan, and Only

Spanish/More British

than Scottish, and Only

British

Other

$-4.791 * * *$

$(0.844)$

$(0.861)$
(0.231)

$-3.289 * * *$

(0.280)

$-1.774 * * *$

(0.303)

\section{Education Level \\ (compared to 'No qualifications')}

Primary level

Secondary level

$\begin{array}{ll}-0.528 & -0.383\end{array}$

(0.738) (0.690)

$-0.449$

$-0.216$

$-0.0581$

0.0326

$-0.117$

0.109

$(0.705)$

(0.523)

(0.489)

$(0.492)$

$(0.614) \quad(0.577)$

0.0716

$-0.397$

$-0.266$

$-0.239$

$-0.581 \quad-0.216$

$(0.593)$

(0.509)

$(0.475)$

$(0.476)$

$(0.617) \quad(0.578)$
-0.902

$-0.230$

$-0.441$

$-0.334$

$-0.344$

equivalent)

$-0.902$

$-0.440$

$(0.594)$

$(0.514)$

$(0.478)$

$(0.479)$

(0.671) (0.627)

$(0.644)$

0.0382

0.256

0.239

or equivalent)

Other

$(0.535)$

$(0.502)$

$(0.505)$

$-0.898$

$-0.630$

$-0.530$

(0.629)

(0.601)

$(0.606)$

\section{Gender (compared to}

'Male')

Female

$\begin{array}{cccccc}-0.0954 & -0.0516 & -0.0490 & -0.677 * * * & -0.585 * * * & -0.569 * * * \\ (0.226) & (0.212) & (0.214) & (0.158) & (0.151) & (0.152) \\ & & & & & \\ -0.0230 & -0.0150 & 0.0281 & -0.161 * * & -0.160 * * & -0.159 * * \\ (0.104) & (0.0957) & (0.0982) & (0.0725) & (0.0707) & (0.0711)\end{array}$

Income

-0.0230
$(0.104)$

(0.0957)

(0.0982)

(0.0725)

$(0.0707)$

(0.0711)

Age (compared to '18-

24' years old)

25-34

0.287

0.290

0.282

0.452

0.277

0.382

$(0.443)$

(0.426)

$(0.425)$

(0.355)

$(0.349)$

(0.355)

$35-44$

$(0.445)$

0.147

0.138

$0.615^{*}$

0.365

0.502

45-54

0.265

$(0.420)$

(0.421)

$(0.357)$

$(0.348)$

(0.356)

(0.471)

$(0.445)$

0.0963

$0.586^{*}$

0.415

0.553

55-64

$-0.327$

$-0.420$

$(0.445)$

(0.352)

$(0.343)$

(0.352)

(0.474)

(0.444)

$-0.127$

$-0.317$

$-0.186$

$>=65$

$-0.352$

$-0.460$

(0.445)

(0.617)

(0.604)

(0.608)

$-0.528$

$(0.506)$

Language spoken at

home (Catalonia;

compared to

'Predominantly

Catalan')

Both Catalan and Spanish $\quad-0.302 \quad-0.630^{* *} \quad-0.665^{* * *}$ 


\begin{tabular}{lccc} 
& $(0.265)$ & $(0.248)$ & $(0.249)$ \\
Predominantly Spanish & $-1.397 * * *$ & $-1.805 * * *$ & $-1.831^{* * *}$ \\
\multirow{3}{*}{ Other } & $(0.285)$ & $(0.273)$ & $(0.275)$ \\
& -0.871 & 0.167 & 0.267 \\
& $(0.747)$ & $(0.839)$ & $(0.881)$
\end{tabular}

\section{Place of residence \\ (Catalonia; compared to \\ the province of \\ Barcelona)}

Tarragona

Lleida

$\begin{array}{ccc}0.865^{* *} & 0.744 * * & 0.736^{* *} \\ (0.361) & (0.357) & (0.355) \\ -0.149 & -0.309 & -0.294 \\ (0.464) & (0.432) & (0.437) \\ -0.522 & -0.628^{*} & -0.529 \\ (0.349) & (0.323) & (0.328)\end{array}$

\section{Place of residence}

(Scotland; compared to

South Western Scotland)

Eastern Scotland

North Eastern Scotland

Highlands and Islands

$\begin{array}{lll}0.0578 & 0.0983 & 0.0869 \\ (0.161) & (0.155) & (0.155) \\ -0.243 & -0.293 & -0.272 \\ (0.308) & (0.302) & (0.303) \\ -0.473 & -0.383 & -0.399 \\ (0.293) & (0.282) & (0.283)\end{array}$

\section{National Identity}

Positive treatment X

National identity

Negative treatment X

National identity

\section{Trust EU}

$\begin{array}{cc}-1.928 * * * & -1.934 * * * \\ (0.278) & (0.282) \\ 0.153 & 0.171 \\ (0.362) & (0.365) \\ 0.621 * & 0.550 * \\ (0.324) & (0.332)\end{array}$

$$
\begin{array}{cc}
-0.593 * * * & -0.602 * * * \\
(0.102) & (0.103)
\end{array}
$$$$
-0.246 \quad-0.226
$$$$
(0.154) \quad(0.155)
$$$$
-0.697 * * * \quad-0.686^{* * *}
$$$$
\text { (0.174) (0.175) }
$$

Positive treatment X Trust

$-0.0323$

$(0.0849)$

$0.101 *$

$-0.0496$

(0.117)

EU

$-0.133$

Negative treatment $\mathrm{X}$

Trust EU

Constant

(0.109)

(1.026)

$3.803 * * *$

$3.946 * * *$

$1.621 * * *$

(0.910)

(0.612)

$(0.0527)$

$-0.0161$

$(0.0731)$

$-0.102$

(0.0795)

$0.971 * \quad 0.387$

Observations

923

923

1,049

$(0.644)$

Standard errors in parentheses

$* * * \mathrm{p}<0.01, * * \mathrm{p}<0.05, * \mathrm{p}<0.1$ 


\section{$\underline{\text { Tables and figures }}$}

\section{TABLE 1: AVERAGE TREATMENT EFFECTS (ATE) FOR CATALONIA AND SCOTLAND}

\section{$(1)$}

Catalonia

VARIABLES

Treatment: Positive vs Neutral

$\begin{array}{ll}0.642 * * & 0.296 \\ (0.269) & (0.180)\end{array}$

Treatment: Negative vs. Neutral

$\begin{array}{ll}-0.0564 & 0.223 \\ (0.267) & (0.181)\end{array}$

Observations

923

1,049

\section{Standard errors in parentheses}

$$
{ }^{* * *} \mathrm{p}<0.01,{ }^{* *} \mathrm{p}<0.05,{ }^{*} \mathrm{p}<0.1
$$


FIGURE 1: AVERAGE TREATMENT EFFECTS ON SUPPORT FOR SECESSION IN CATALONIA AND SCOTLAND WITH 95\% CIS

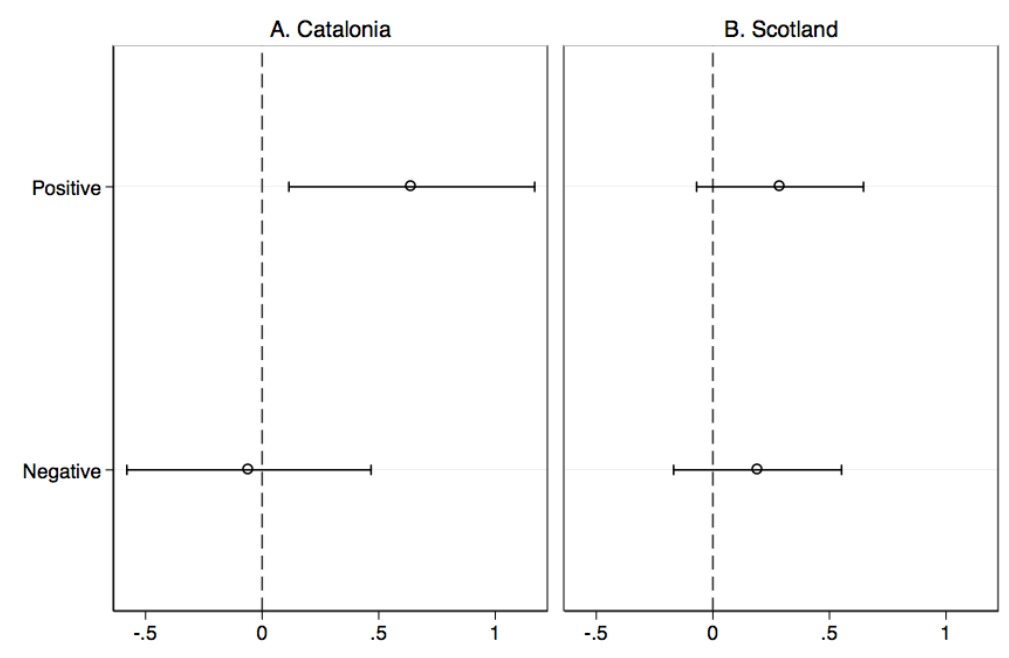

FIGURE 2: AVERAGE MARGINAL TREATMENT EFFECTS ON SUPPORT FOR SECESSION IN CATALONIA AND SCOTLAND BY NATIONAL IDENTITY WITH 95\% CIS

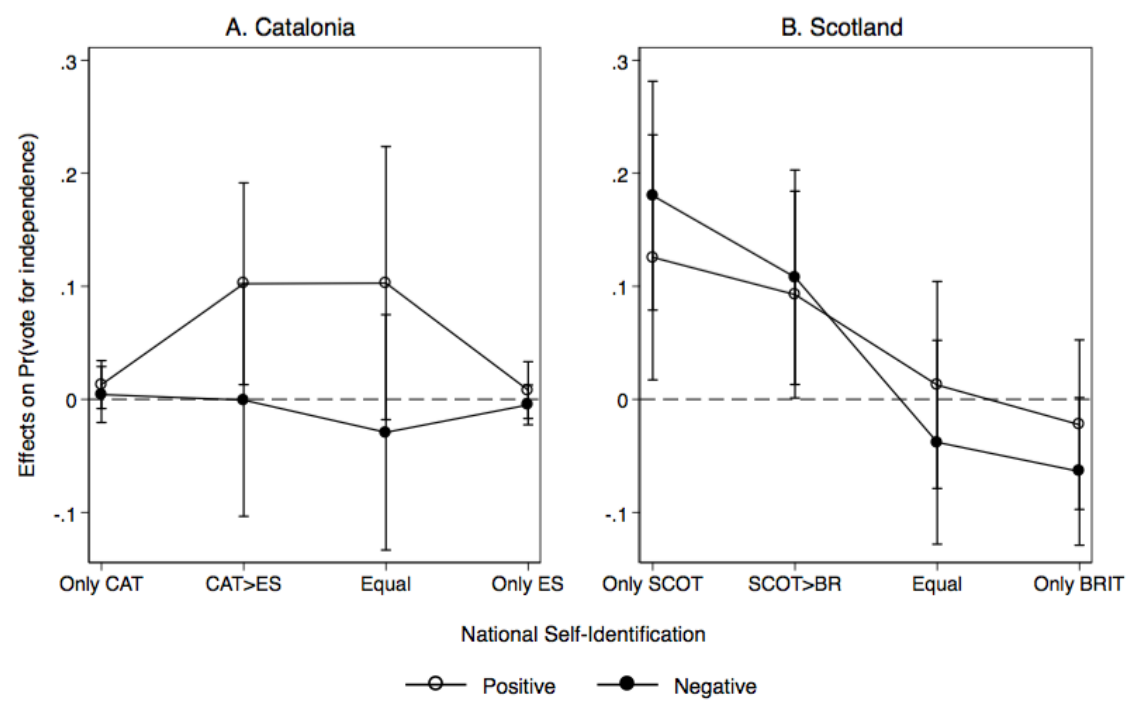


FIGURE 3: SELF-EVALUATION OF IMPACT OF TREATMENT ( $1=$ 'NOTHING' TO 5= 'A LOT') BY NATIONAL SELF-IDENTIFICATION IN CATALONIA AND SCOTLAND

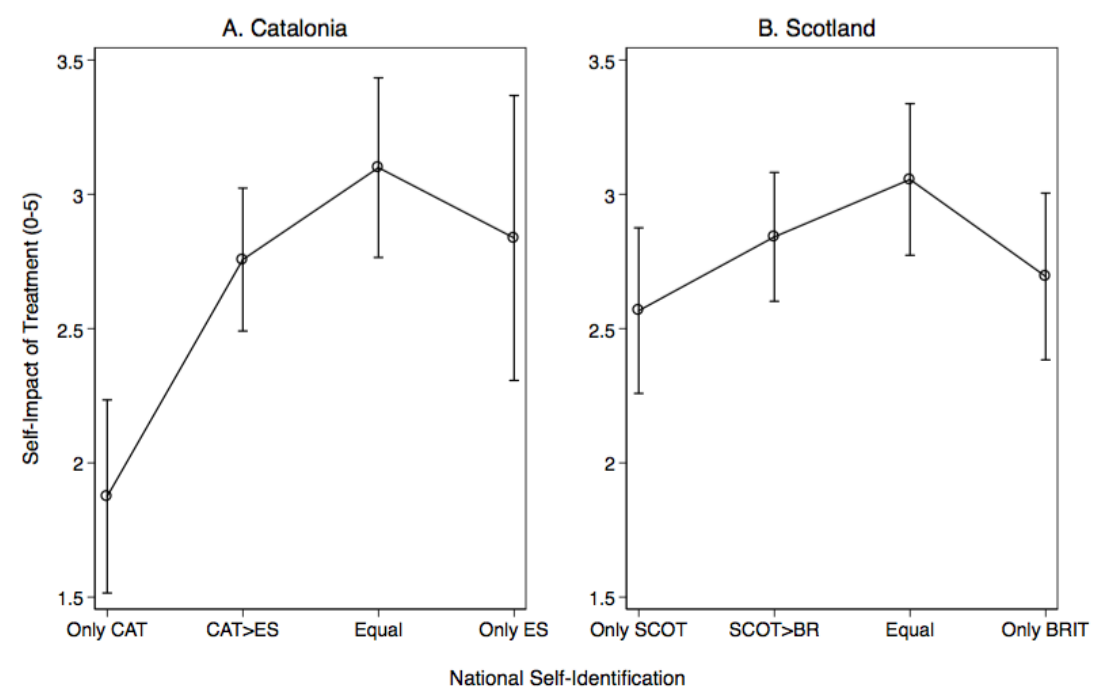

FIGURE 4: AVERAGE MARGINAL TREATMENT EFFECTS ON SUPPORT FOR SECESSION IN CATALONIA AND SCOTLAND BY LEVEL OF TRUST IN THE EU ( $(0=$ 'NO CONFIDENCE' TO 10 = 'COMPLETE CONFIDENCE') WITH $95 \%$ CIS 


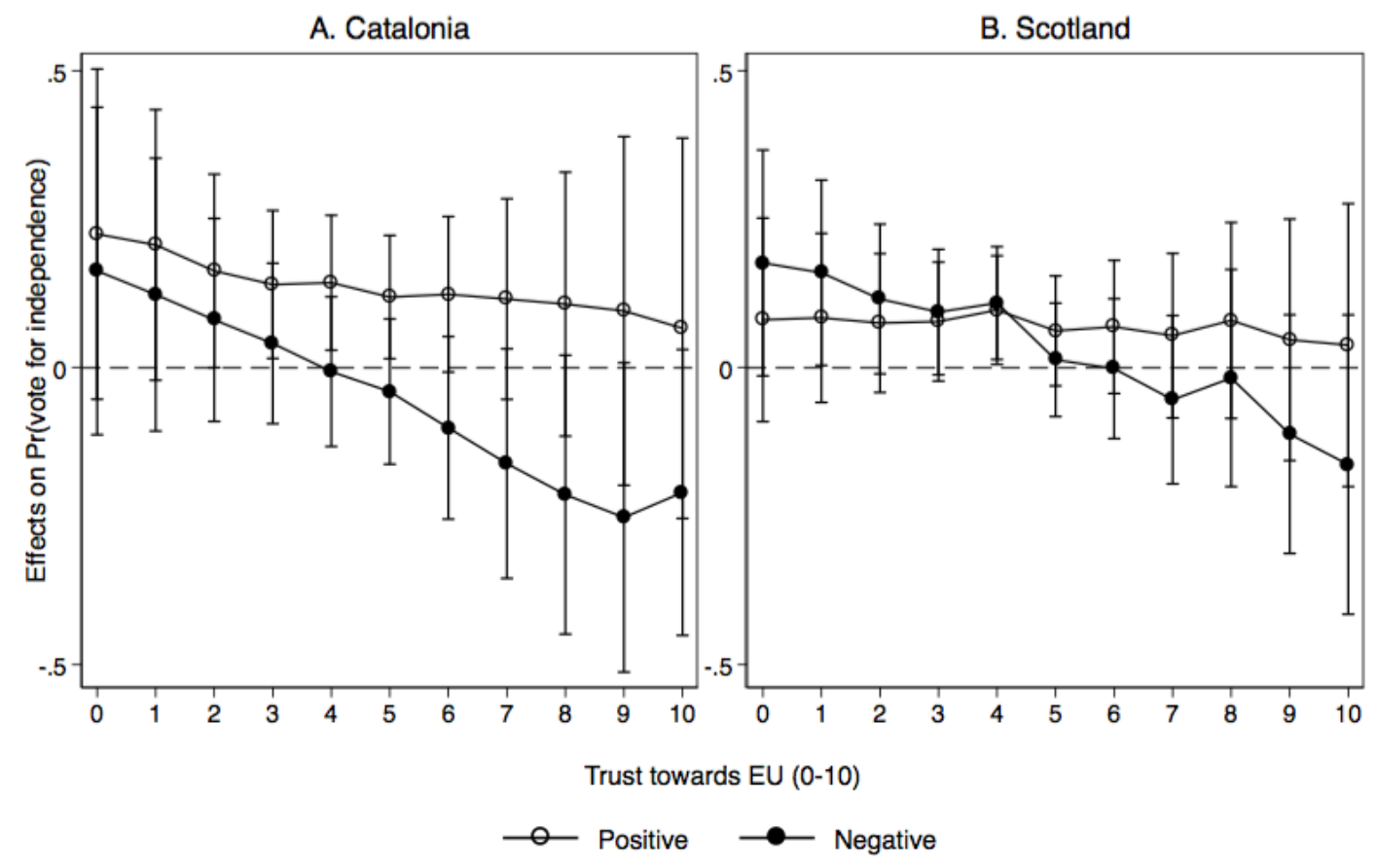

